\title{
The research on producing modes of well AH2 in Jinzhou oilfield Xu Zhang ${ }^{1, a}$, Wei Hua Liu ${ }^{1, b^{*}}$ Jie Liang ${ }^{1, c}$, Yu Pan ${ }^{1, d}$ Teng LV ${ }^{1, e}$ \\ ${ }^{1}$ Chongqing University of Science \& Technology, China \\ azhang163xu@163.com, ${ }^{b} w e i h u a l i u 163 @ 163 . c o m,{ }^{c} 1976884304 @ q q . c o m$, d252008961@qq.com, ${ }^{8} 857756475 @ q q . c o m$
}

Keywords: Jinzhou oilfield, typical well, producing modes

Abstract: The oil in place of Jinzhou oilfield is more than $7000 \times 10^{4} \mathrm{~m}^{3}$. Because of good reservoir properties and adequate formation energy, the field has good developing prospects. However, with the end of flush stage after developing for years, we have to solve the problems such as which mode of production we should take for wells and when we should do that. Based on the dynamic analysis about typical well $\mathrm{AH} 2$, we give out the producing mode of the well in the future by production forecast and nodal analysis. It is indicated that the production of well $\mathrm{AH} 2$ can be increased from $8.1 \mathrm{~m}^{3} / \mathrm{d}$ to $37.5 \mathrm{~m}^{3} / \mathrm{d}$ with the new mode.

\section{Introduction}

The oil in place of Jinzhou oilfield is more than $7000 \times 10^{4} \mathrm{~m}^{3}$. The porosity of the reservoir is from $10.8 \%$ to $40.1 \%$, the permeability is from 0.1 to $1687.8 \mathrm{mD}$, and the pressure coefficient is 1.01. There are more than 40 wells with depletion development at present. The good properties of the reservoir bring great prospects of development.

However, with the procedure of oil developing, some prominent problems are coming. The producing mode of well should be adjusted because the energy of the reservoir is no longer enough. And the beginning time for new mode should be found out. With the production characteristics analysis of typical well $\mathrm{AH} 2$, the paper has pointed out the next mode for $\mathrm{AH} 2$, and has given a conclusion about when the new node should be taken.

\section{Production performance}

AH2, a typical well in Jinzhou Oilfield, was opened to produce in November 2011, using depletion development method. The initial daily production of oil was $161 \mathrm{~m}^{3}$, water was $0.32 \mathrm{~m}^{3}$, and production GOR was $90 \mathrm{~m}^{3} / \mathrm{m}^{3}$. The current of oil is $26 \mathrm{~m}^{3}$, GOR is $420 \mathrm{~m}^{3} / \mathrm{m}^{3}$, and water is not changing. Up to May 2015, the cumulative oil production is $72455 \mathrm{~m}^{3}$, gas is $2325 \times 10^{4} \mathrm{~m}^{3}$ (Fig.1).

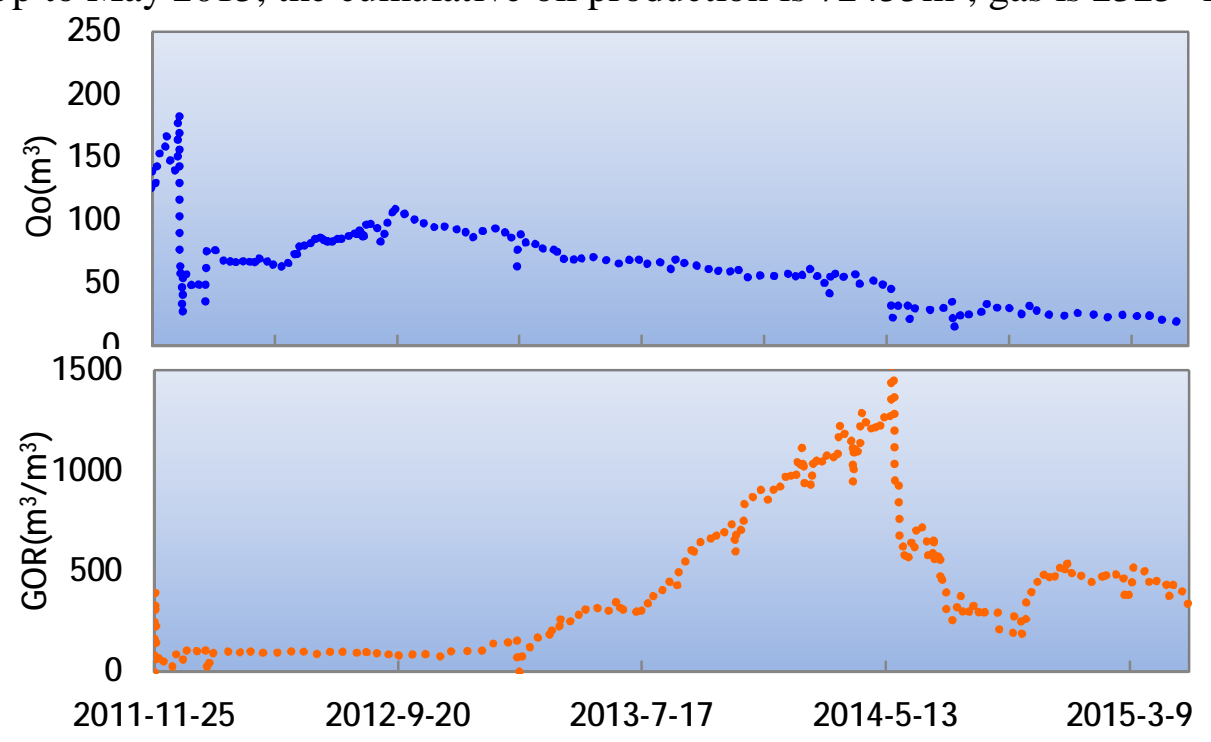

Fig. 1 Production dynamic curve of well AH2

The overall production situation is not stable in this well. The range of production changing is 
relatively large: oil production decreased from $161 \mathrm{~m}^{3} / \mathrm{d}$ to $26 \mathrm{~m}^{3} / \mathrm{d}$, down by $84 \%$; gas-oil ratio increased fast with the obvious dissolved gas driving characteristics. From the dynamic changes throughout the production situation, the well is nearing the late period of depletion. It is urgent to take artificial lift to continue producing.

If we continue to take the current producing mode for $\mathrm{AH} 2$, according to the decreasing analysis, the production will drop to $6 \mathrm{~m}^{3} / \mathrm{d}$ in June 2017, nearing stop flowing (Fig.2, Table 1). The dynamic reserves of the well is about $50.6 \times 10^{4} \mathrm{~m}^{3}$, which has been mined $72455 \mathrm{~m}^{3}$ currently, the recovery percent of reserve is only $14.3 \%$, so the Well has good development potential.

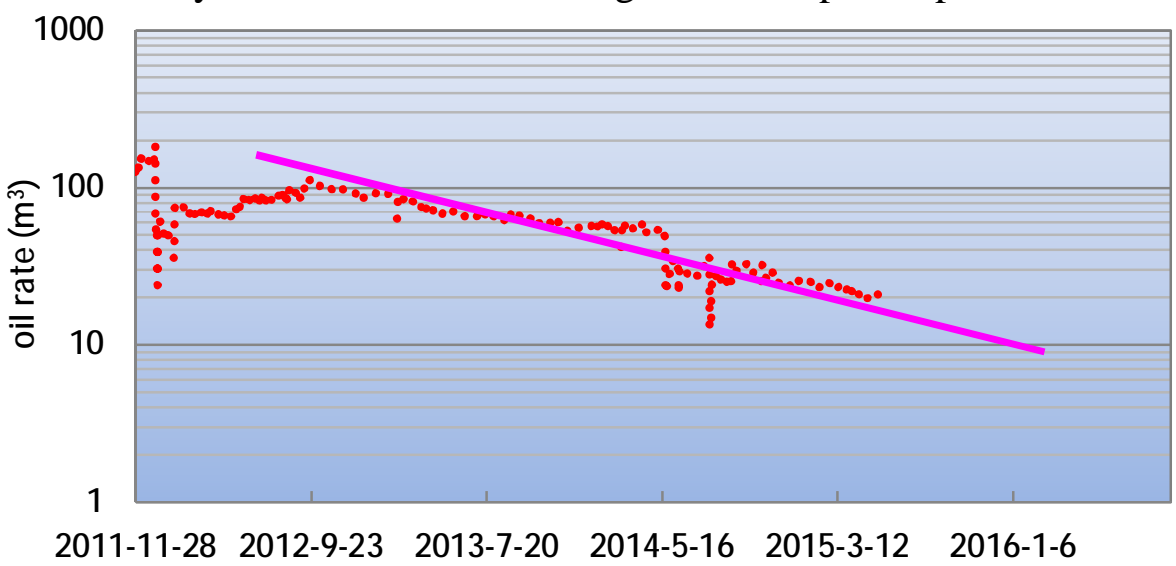

Fig. 2 Production decline analysis curve of well AH2 Table 1 Production prediction table of well $\mathrm{AH} 2$

\begin{tabular}{|c|c|c|c|}
\hline time & $\mathrm{Q}\left(\mathrm{m}^{3} / \mathrm{d}\right)$ & time & $\mathrm{Q}\left(\mathrm{m}^{3} / \mathrm{d}\right)$ \\
\hline 2015.3 & 23.7 & 2016.6 & 11.1 \\
\hline 2015.6 & 20.6 & 2016.9 & 9.5 \\
\hline 2015.9 & 17.6 & 2016.12 & 8.1 \\
\hline 2015.12 & 15.1 & 2017.3 & 7 \\
\hline 2016.3 & 12.9 & 2017.6 & 6 \\
\hline
\end{tabular}

\section{Artificial lift optimization}

According to the comprehensive parameters weighted method, we can find out a appropriate artificial lift way to $\mathrm{AH} 2$, based on many factors such as technology, process, use, economy and society.

Use $\mathrm{Z}$ represents the integrated parameters, it can be calculated by the following formula:

$$
\mathrm{Z}=\sqrt{\bar{X} \bar{Y}} ; \quad \overline{\mathrm{X}}=\sqrt[n]{\Pi_{i}^{m} X_{i}} ; \quad \overline{\mathrm{Y}}=\sqrt[m]{\prod_{i}^{m} Y_{i}}
$$

Where:

Z--Comprehensive parameter values for artificial lifting evaluation;

$\overline{\mathrm{X}}, \overline{\mathrm{Y}}$-- values of partial comprehensive parameters;

$\mathrm{Xi}$, Yi--values of partial parameters;

$\mathrm{n}, \mathrm{m}$--the total number of partial parameters $\mathrm{X}, \mathrm{Y}$.

Using this method to evaluate for well AH2, the results are shown in Table 2.

Table 2 Comprehensive parameters calculation results of artificial lift

\begin{tabular}{|c|c|c|c|c|c|c|c|c|}
\hline $\begin{array}{c}\text { Ways } \\
\text { Of Lift }\end{array}$ & $\begin{array}{c}\text { Rod } \\
\text { pump }\end{array}$ & $\begin{array}{c}\text { Ground Drive } \\
\text { Screw }\end{array}$ & $\begin{array}{c}\text { Hydraulic } \\
\text { pump }\end{array}$ & $\begin{array}{c}\text { Hydraulic } \\
\text { Jet Pump }\end{array}$ & $\begin{array}{c}\text { Submersible } \\
\text { Pump }\end{array}$ & $\begin{array}{c}\text { Booster } \\
\text { Station } \\
\text { Gas lift }\end{array}$ & $\begin{array}{c}\text { Plunger } \\
\text { Lift }\end{array}$ & $\begin{array}{c}\text { Bailing } \\
\text { produce } \\
\text { oil }\end{array}$ \\
\hline $\mathrm{Z}$ & 1.86 & 2.17 & 2.10 & 2.17 & 2.40 & 2.69 & 1.63 & 1.63 \\
\hline
\end{tabular}

According to the optimization results for well $\mathrm{AH} 2$, considering the economy, gas oil ratio, gas supply and other factors, we recommend gas lift as the next producing mode to the well. 


\section{Artificial lift timing analysis}

Through nodal analysis for well $\mathrm{AH} 2$, we can obtain the nature flow-stop pressure and production. Then the artificial lift timing can be given with production forecast of the well.

From the nodal analysis and production prediction of the well (Fig.3), we can see that the production will decrease to $8.1 \mathrm{~m}^{3} / \mathrm{d}$ in December 2016, when the artificial lift would be taken.

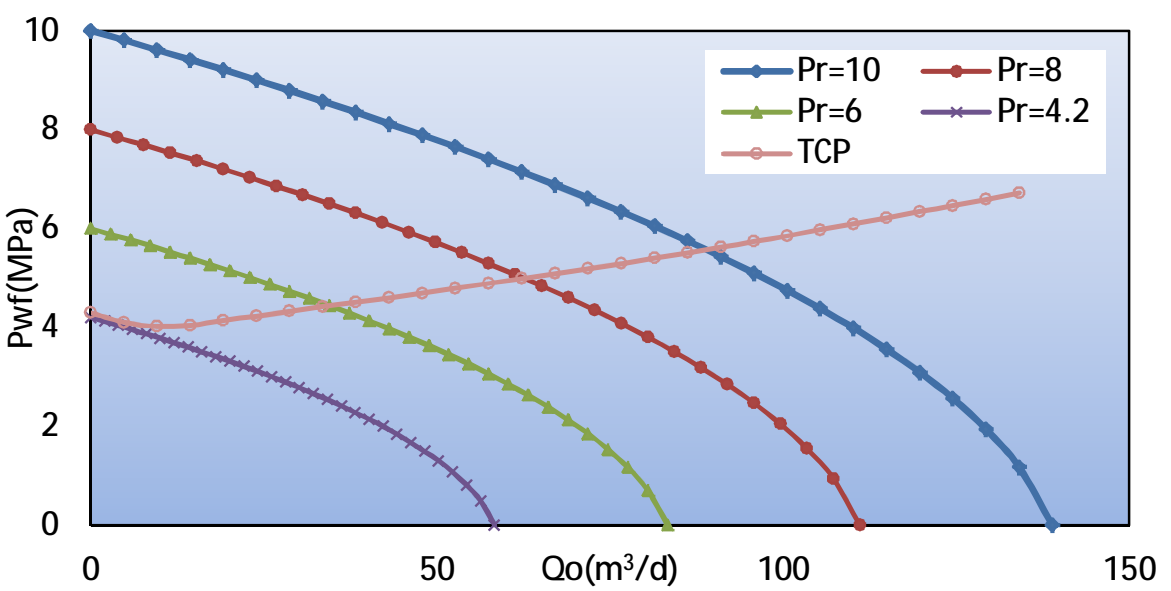

Fig. 3 Node analysis curve of well AH2

\section{Artificial lift design and effect forecast}

According to the result of artificial lift optimization for well AH2, the gas lift design has been done (the design results are shown in Fig.4 and Table 3). There will be three levels of gas lift valves in the well; the injecting depth is $1874 \mathrm{~m}$; and the volume of injecting gas is $0.5 \times 10^{4} \mathrm{~m}^{3} / \mathrm{d}$. After all, the production of well $\mathrm{AH} 2$ will be increased remarkably to $37.5 \mathrm{~m}^{3} / \mathrm{d}$.

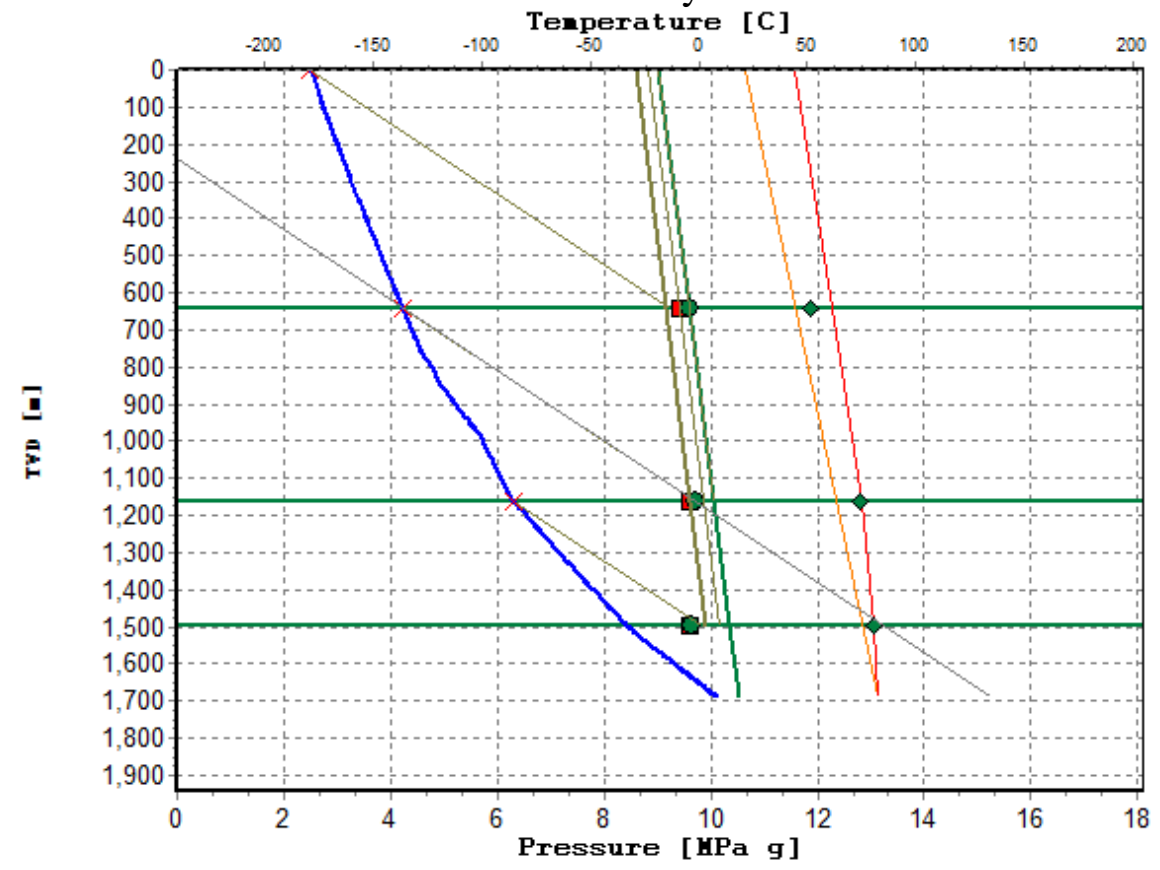

Fig. 4 Gas lift design maps of well AH2

Table 3 Gas lift design table of well AH2

\begin{tabular}{|c|c|c|c|c|c|c|c|c|}
\hline $\begin{array}{c}\text { Sequence } \\
\text { number }\end{array}$ & $\begin{array}{c}\text { MD } \\
(\mathrm{m})\end{array}$ & $\begin{array}{c}\text { Valve } \\
\text { diameter } \\
(\text { inches })\end{array}$ & $\begin{array}{c}\text { Ptro } \\
(\mathrm{MPa})\end{array}$ & $\begin{array}{c}\text { Valve } \\
\text { temperature } \\
\left({ }^{\circ} \mathrm{C}\right)\end{array}$ & $\begin{array}{c}\text { Closed } \\
\text { pressure } \\
(\mathrm{MPa})\end{array}$ & $\begin{array}{c}\text { Open } \\
\text { pressure } \\
(\mathrm{MPa})\end{array}$ & $\begin{array}{c}\text { Uninstall } \\
\text { amount } \\
\left(\mathrm{m}^{3} / \mathrm{d}\right)\end{array}$ & $\begin{array}{c}\text { gas } \\
\text { injection } \\
\left(10^{4} \mathrm{~m}^{3} / \mathrm{d}\right)\end{array}$ \\
\hline 1 & 659 & $1 / 8$ & 8.551 & 51 & 8.84 & 9 & 24.16 & 0.177 \\
\hline 2 & 1386 & $1 / 8$ & 8.069 & 74.3 & 8.598 & 8.695 & 35.57 & 0.478 \\
\hline 3 & 1874 & $1 / 8$ & 7.922 & 80.3 & 8.357 & 8.39 & 37.48 & 0.5 \\
\hline
\end{tabular}




\section{Conclusions}

From the dynamic analysis on typical well AH2 of Jinzhou oilfield we can see that the well has been nearing the late depletion period, and it is urgent to take artificial lift to continue production. Through comprehensive analysis, the mode for further developing of well AH2 is gas lift. The timing to take artificial lift measure is before December 2016. and the production will be increased to $37.5 \mathrm{~m}^{3} / \mathrm{d}$ by gas lifting.

\section{Acknowledgments}

This work was funded by Scientific and Technological Research Program of Chongqing Municipal Education Commission (Grant No. KJ1501335), and Natural Science Fund of Chongqing science \& technology commission (Grant No.cstc2012jjA90014).

\section{References}

[1] Jianchun Guo and Hai Tang, Oil and gas reservoir development and exploitation technology, Beijing, Petroleum Industry Press, 2013.

[2] Hongyou Zhang and Yuejie Wang, Calculation of dynamic reserves of reservoir pressure drop curve by permanent downhole gauge, Oil and gas well testing, 2010.

[3] Yinchuan Li, Oil production engineering, Beijing, Petroleum Industry Press, 2002.

[4] Mofazzal Bhulyan, Designing and evaluating artificial lift systems-acombined approach, offshore engineer, 2006.

[5] Yongliang Sun, Optimization design of gas lift, China University of Geosciences, 2012. 